\title{
Noninterest Income and Financial Performance at Jordanian Banks
}

\author{
Alaaeddin Al-Tarawneh ${ }^{1}$, Bashar K. Abu Khalaf ${ }^{1} \&$ Ghazi Al Assaf ${ }^{1}$ \\ ${ }^{1}$ Assistant Professor, School of Business, The University of Jordan, Jordan \\ Correspondence: Bashar K. Abu Khalaf, Assistant Professor, School of Business, The University of Jordan, Jordan.
}

Received: January 3, 2017

Accepted: January 11, 2017

Online Published: January 22, 2017

doi:10.5430/ijfr.v8n1p166

URL: http://dx.doi.org/10.5430/ijfr.v8n1p166

\begin{abstract}
This paper investigated the impact of noninterest income on the performance of 13 banks in Jordan during the period 2000-2015. The impact of size of bank, loans, capital adequacy and overhead expenses on banks performance found to have a significant impact on banks performance. In more details, overhead expenses decrease bank performance, while capital adequacy, loans and size increase it. In addition, non-interest income increases equity capital adequacy and this in turn affects the profitability positively.
\end{abstract}

Keywords: noninterest income, performance, Jordanian banks, Amman Stock Exchange

\section{Introduction}

A bank is a corporation that allows its customers to deposit money and demand loans. Other services offered by banks are investment products. In other words, a bank is a financial business that deals with money and credit. Financial performance measures the efficiency of banks and the systems in which they operate in. Financial performance is of great importance as it is an indicator of profitability and the success of the overall economy (Almazari, 2011).

There are two types of banks in Jordan; the first type is Islamic banks, which uses the basic principles of Islamic sharia. Islamic banking is also recognized as interest free banking as the sharia refuses the acceptance of "riba" or the interest rate for accepting and borrowing money, meaning that this type of banking depends on noninterest forms of income (Karakaya \& Er, 2013). The second type is Commercial Banks, which provide financial services to the general public and to governments in exchange for revenue. Commercial banks lend money to customers and charge a rate of interest that is higher than what the bank pays to other banks or to customers with deposits at the bank. The difference between the interest income and interest expense is termed; net interest income, which is an important measure of financial performance.

Basically, there are two forms of income; interest income and noninterest income. A bank's income statements include a separate section for the second type of income (non-interest income). Typical sources of noninterest income include service charges on deposit accounts, credit fees, securities transactions, and trading account profits (losses). Noninterest income has become a legitimate activity of banks. Its importance is highly increasing and makes up $40 \%$ of operating income in the U.S. commercial banking industry as stated in the De Young and Rice (2003). Therefore, banks are increasingly depending on noninterest income for their survival and success in generating revenues and profit (Bian et.al. 2015).

A few studies empirically questioned the relation between noninterest income and financial performance of banks. A conclusion from DeYoung and Roland (2001) is that larger banks with specialized strategies depend more heavily on noninterest income than smaller banks with traditional business strategies. In Barbados researchers found that noninterest income was connected to bank profitability and earnings volatility. Commercial banks in Jamaica have showed a growing reliance on income generated from noninterest activities, which has also been shaped by the distinct expand of ATM and POS technology as affirmed by Bailey-Tapper (2010). Additionally, De Young and Rice (2003) noticed acceleration in the rapid growth of noninterest income compared with periods of sharp macroeconomic volatility.

In this study the noninterest form of income and its effect on the financial performance of the banking sector in Jordan will be taken into consideration. 


\section{Literature Review}

DeYoung and Rice (2003) investigated how financial performance is related to business strategies, technological changes and advances, market conditions, and most importantly noninterest income in a study conducted on U.S commercial banks. The results were that banks with better management expanded in a slower pattern into noninterest activities and increase in noninterest income is generally linked to poor risk-return tradeoffs. The conclusion was that noninterest income is not replacing the interest income, which is the main activity of banks; rather, both sources of income are co-existing to add to the financial performance of the banking sector.

Karakaya and Bunyamin, (2012) studied the performance of an emerging market, (Turkey) taking into consideration the years $2005-2010$. The study was conducted for the purpose of examining the relation between noninterest income and the determinants of bank profitability, as well as bank performance. This study took into consideration several factors that have an impact on bank performance which are capital adequacy, credit rate, credit provision rate and size of the bank. They concluded that capital adequacy, credits, and size enhance the performance of banks whereas general expenses tend to decrease it.

Rahman et. al. (2015) used a sample of 25 commercial banks for the period 2006-2013 from Bangladesh, considering potential bank profitability determinants such as liquidity, non-interest income, off-balance sheet activities, bank size, capital strength, credit risk, ownership structure, cost efficiency, and inflation. Using various measures of profitability, some of which are return on assets (ROA), return on equity (ROE), as well as net interest margin over total assets. Results showed that there is a negative impact on profitability coming from cost efficiency and off-balance sheet activities; meanwhile there is a positive impact from loan intensity and capital strength on bank profitability. Other empirical findings indicate that credit risk, and Non-interest income are established important for determining net interest margin (NIM). They also found that there is a positive relationship between size and (ROA), and that inflation has a negative relation to (ROA) and (ROE).

Bailey-Tapper (2010) applied a Seemingly Unrelated Regression model for the periods of 1999 to 2010 to confirm empirical connections among financial performance, non-interest income, and the macro economy in Jamaica. The factors that are enhancing performance in noninterest income in commercial banks are loan quality, personal lending, and ATM technology, as for the macroeconomic environment, volatility in foreign exchange rate and interest rate.

Bashir (2003) empirically investigated the financial environment and bank characteristics impact on the performance of Islamic banks. Eight Middle Eastern countries (Bahrain, Qatar, Sudan, Turkey, Egypt, Jordan, Kuwait, and U.A.E.) were included in the study over the period of 1993-1998. The purpose of the study was to predict efficiency and profitability based on a set of internal and external characteristics. The empirical findings of the study suggest that profitability has a positive relationship with leverage ratio (loan to asset ratio) as well as capital to asset ratio, and banks with foreign owners are more profitable.

Alzoubi (2015) examined 33 commercial banks and 10 Islamic banks from Kuwait, Saudi Arabia, United Arab Emirates (UAE), and Jordan, covering the years 2007 - 2013. A comparative study methodology was applied in order to check the differences between conventional and Islamic banks. The results showed that Islamic and conventional banks do not differ in profitability and growth rate of assets in Islamic banks are higher than those of conventional banks.

Stiroh (2002) investigated how U.S. Banking industry is constantly increasing dependence on nontraditional business activities that induce fee income, trading revenue and other noninterest income. Stiroh assumes that there are benefits to potential diversification from this shift. As net operating revenues volatility declines, it reflects cut-price volatility of net interest income. The reason that noninterest income became more correlated to net interest income and more volatile is the result of the advantages of diversification.

Based on the previous literature review about noninterest income and its impact on financial performance, it is concluded that noninterest income and interest income co-exist, instead of replacing one another in order to increase a bank's financial performance. Each study took different variables into consideration some of which are the bank's size, capital adequacy, operational efficiency and asset management.

\section{Methodology}

The data used in the analysis of this study is composed of 13 Jordanian banks. The analysis will be on a period of 16 years, from 2000-2015. The data has been collected from each bank's annual reports, financial statements, and information available on the Amman Stock Exchange website. 


\subsection{Dependent Variable}

\section{Profitability}

Profitability ratios are an indicator of financial performance. The main measure of the overall performance of a bank is return on assets (ROA), which is measured by the ratio of net profit to total assets. This measure comprises two components, effectiveness (profit margin), and efficiency (total assets turnover). It reflects the bank management's ability to generate profits by using the available financial and real assets of the bank (Almazari, 2011). ROA has been used in several studies for the purpose of reflecting profitability and is included to reflect the bank's ability to generate income from non-traditional services (Rahman et.al. 2015). ROA shows the profit earned per dollar of assets and it reflects the management's ability to put the bank's financial and real assets to good use in generating profits (Edirisuriya et.al. 2015).

\subsection{Independent Variables}

\subsubsection{Capital Adequacy}

Capital Adequacy Ratio (CapRatio) is the ratio of equity to total assets. It shows how competent owners' investments in a bank are compared to its liabilities. An extremely high capital adequacy ratio is an indication that a bank is being extra cautious and neglecting profitable investment opportunities. Conversely, Rogers and Sinkey (1999) assume that banks with high levels of capital are better able to consume asset losses from nontraditional activities. Damankah et. al. (2014) found a positive relationship between capital adequacy ratio and net interest income, but if highly leveraged banks are more involved in nontraditional activities, moral-hazard behavior could be dominating and a negative relationship between Net interest income and Capital Ratio will appear. Based on the study performed by Karakaya \& $\operatorname{Er}(2013)$, they showed that assets profitability is higher with banks that have higher capital adequacy and a larger in size. Therefore, we expect that Capital adequacy is positively associated with the financial performance of a bank.

\subsubsection{Overheads}

Overheads are the cost of operating a business. It is essential to any business by providing the support needed to generate profit, therefore, it is an indirect expense. It is used to provide feedback on variation in operation costs across the banking system. It provides an indication of employment, total amount of salaries and wages, as well as the cost of running branch office facilities. Based on Karakaya \& Er (2013) study on the Turkish banking sector, it was concluded that larger banks have higher overheads than smaller banks. A high overhead ratio is expected to impact the financial performance of a bank negatively because efficient banks are expected to have relatively lower cost of operations. Similarly, Bashir (2003) that the usage of new electronic technology like ATMs, internet and other automated ways of delivering services, has caused the salaries expense to fall, therefore, decreasing the overhead expense and consequently increasing the bank's profitability. This paper used the ratio of overheads to operating income as a measure of a bank's overheads. Thus, we expect that Overheads are negatively associated with the financial performance of a bank.

\subsubsection{Loans}

Loans are an agreement between a customer and a bank in which the bank lends the customer a sum of money in exchange for an interest fee. They are expected to be the main source of revenue for banks. Bashir (2003) argued that loans are expected to affect a bank's profitability positively. However, the economic fluctuations should be taken into consideration. The relationship between loans and profitability depends on the changes of the economy. During an economic expansion, only a small percentage of loans will default, therefore, increasing the banks' profits. On the other hand, during a weak economy, a bank could be severely affected because the percentage of customers that might default will increase. Banks therefore, should try to maximize their profits in favorable economic conditions and be extra cautious in economic recessions.

DeYoung and Roland (2001) suggested three reasons why the volatility of bank earnings increases as a result of noninterest income. The first reason is that most bank loans are relationship based and as a result have high switching costs, while most fee-based activities are not relationship based. As a result, interest income from loans may be less volatile than noninterest income from fee-based activities. The second reason is that the main input needed to produce more loans is interest expense. On the other hand, the main input needed to produce fee-based products is fixed cost (labor expense). Therefore, fee-based activities may require greater operating leverage than lending activities, which makes bank earnings more vulnerable to decline in bank revenues. The final reason is that most fee-based activities require banks to hold limited or zero fixed assets, contrary to interest based activities. Thus, fee-based activities usually use more financial leverage than lending activities. According to multiple studies such as 
Karakaya \& Er, (2013); Bian et.al. (2003) and Almazari, (2011) a positive relationship was proven between banks' profitability and loans. This paper used the ratio of loans to total assets as a measure of a bank's loans. Hence, we expect that Loans are positively associated with the financial performance of a bank.

\subsubsection{Size}

Haron (1996) empirically investigated the effectiveness of external variables on the performance of Islamic banks. He used information from 14 Islamic banks from 10 countries for the period 1982 - 1994. He concluded that Islamic banks in competitive markets do better than monopolistic banks. Almazari, (2011) and Bashir (2003) found positive relationship between bank size and financial performance was proven. He showed that bank size could be a key factor that positively reflects the performance of a bank and its profitability; therefore it improves the returns of the bank creating more resources to generate funds. Karakaya \& Er, (2013) discussed that size has a positive relationship with profitability. They also showed that the profitability of Islamic banks is higher than that of commercial banks and larger banks gain higher profits than smaller ones. DeYoung \& Rice, (2003) suggested that fee-based services are relatively new and many small community banks lack the size and expertise to engage in these activities.

On the other hand, larger banks with more assets have a higher potential of minimizing risk by diversification, hence getting higher returns. Damankah et al, (2014) argued the importance of a bank's size and its influence in the degree of engagement in interest and non-interest earning activities. They concluded that banks in richer countries are larger in size, which as a result promotes economies of scale and reduces the costs of gathering and processing information. In addition, larger banks are better able to engage in a larger menu of service, therefore acquiring more funds. This paper used the natural logarithm of total assets as a measure of size. Consequently, we expect that there is a relationship between the size of a firm and the financial performance of a bank.

\subsubsection{Noninterest Income Margin}

Noninterest income margin is measured by noninterest income to total assets. The noninterest income activities have increased in banks due to the usage of new technologies caused by the increased competition with other financial institutions as a result of deregulation. This deregulation process allowed banks to use technologies in a more effective manner. An increase in noninterest income can also be the result of a bank increasing their fees because of external forces of the market (Karakaya \& Er, 2013). This study expects positive association between Non Interest Income Margin and financial performance of a bank.

\section{Model}

This paper estimate the following model using the fixed and random effect techniques, then, Hausman test is applied in order to specify the best model;

$$
\text { ROA }_{i, t}=\alpha_{0}+\alpha_{1} \text { NoninIncome }_{i, t}+\alpha_{2} \text { CapRatio }_{i, t}+\alpha_{3} \text { Overheads }_{i, t}+\alpha_{4} \text { Loans }_{i, t}+\alpha_{5} \text { Size }_{i, t}+\varepsilon_{i}
$$

Where: ROA is return on assets measured by net income divided by total assets; NoninIncome is measured by noninterest income to total assets; CapRatio is capital adequacy measured by the equity ratio; Overheads is measured by overheads divided by operating income; Loans is measured by loans divided by total assets; Size is measured by the natural logarithm of total assets.

\section{Results}

The descriptive statistics and correlation Matrix of the different variables of this study are shown in Table 1 and Table 2 respectively.

Table 1. Descriptive statistics

\begin{tabular}{llllll}
\hline & Minimum & Maximum & Mean & Median & St.Dev. \\
\hline Return On Assets & 0.000 & 0.625 & 0.045 & 0.046 & 0.035 \\
\hline Noninterest Income Margin & -0.052 & 0.325 & 0.018 & 0.014 & 0.521 \\
\hline Capital Adequacy & 0.000 & 0.545 & 0.105 & 0.108 & 0.085 \\
\hline Overheads & 0.035 & 0.785 & 0.385 & 0.391 & 0.205 \\
\hline Loans & 0.345 & 0.850 & 0.534 & 0.545 & 0.025 \\
\hline Size & 7.901 & 12.240 & 9.490 & 9.580 & 0.852 \\
\hline
\end{tabular}


It is worth to mention that Table 1 shows that the highest standard deviation is for the size. This reflects that in the Jordanian market there is a huge differentiation in terms of total assets between banks. In addition, some of the banks faced negative Noninterest Income Margin and this indicates that in a certain year one of the banks at least faced higher noninterest expenses compared to their noninterest income.

Table 2 presents the correlation coefficients between the different variables. Correlation coefficients do not only show the relation levels among variables, but can also point to the problem of high multi-collinearity relation among the variables used in this model. However, the VIF test shows that there is no multi-collinearity problem using these variables since all of the factors are below 6. Moreover, there is a negative correlation between Capital Adequacy ratio, size and loans. This means that small banks adopt tighter loan policy and have higher capital adequacy. Conversely, banks' overheads and their sizes share a positive correlation, which proves that large banks naturally assume higher overheads.

Table 2. Correlation matrix

\begin{tabular}{|c|c|c|c|c|c|c|}
\hline Variables & Noninterest Income Margin & Capital Adequacy & Overheads & Loans & Size & VIF \\
\hline Noninterest Income Margin & 1 & & & & & 1.597 \\
\hline Capital Adequacy & 0.242 & 1 & & & & 1.842 \\
\hline Overheads & 0.468 & 0.049 & 1 & & & 1.649 \\
\hline Loans & 0.297 & -0.294 & -0.108 & 1 & & 2.154 \\
\hline Size & 0.651 & -0.354 & 0.250 & -0.157 & 1 & 1.289 \\
\hline
\end{tabular}

Table 3. The panel data analysis findings of return on assets, fixed effect results

\begin{tabular}{ll}
\hline constant & $0.594^{*}$ \\
\hline Noninterest Income Margin & $1.567^{* * *}$ \\
\hline Capital Adequacy & $0.167^{* *}$ \\
\hline Overheads & $-0.649^{*}$ \\
\hline Loans & $0.913^{* * *}$ \\
\hline Size & $0.917^{* * *}$ \\
\hline Adjusted $\mathrm{R}^{2}$ & 0.28 \\
\hline F statistic & $3.946^{* * *}$
\end{tabular}

Note: $* * *, * * *$ show the statistical significance levels at $0.11,0.05$ and 0.01 respectively

The results presented in Table 3 are based on the fixed effect model after applying Hausman test. As observed in Table 3, Noninterest Income Margin, Capital Adequacy, Loans and Size have a positive significant effect on bank profitability. This proves that asset profitability raises more at the banks with higher capital adequacy and larger size because they are more willing to provide more loans in the Jordanian market. In addition, Overheads have negative effect which indicates that banks which have lower expenses have higher profitability. In other words, banks which pay less interest due to strong capital structure can benefit from competition advantage stemming from being large in size and can make savings in the expenses increase profitability.

Table 3 shows that there is a positive and significant effect of noninterest income margin on banks profitability and this confirms that the profitability of Jordanian banks increase if they concentrate in increasing their noninterest income through increasing the charges and fees paid by their customers. In other words, larger banks usually have better Capital Adequacy and can lend more which increases the number of clients that banks have and this in return can affect the noninterest income to increase and consequently the performance of banks.

\section{Conclusion}

The basic role of banks is the financial intermediation between depositors and borrowers and obtaining their income through two main activities. First, the interest income which is the difference between the interest paid on deposits 
and the interest received form loans- the deposits enable the banks to grant more loans for which they receive interest as operating income. Second, the noninterest income which is the different charges and fees paid as a result of the different services provided by the banks. Banks, especially in the most developed countries have gradually expanded their sources of income by expanding into a wider menu of services and activities that help generate noninterest income. This paper investigated the impact of noninterest income on the financial performance of Jordanian banks. This paper concluded that asset profitability increases with greater size and capital adequacy. Also, it has been observed that profitability of banks that grant more loans and make more savings on overheads become higher. Finally, non-interest income increases the profitability of a bank. Finally, it is worth raising the point that the importance of this paper stems from the fact that banks do promote real economic growth. In other words, it is always useful to examine the performance of such important institutions.

\section{Acknowledgments}

We would like to acknowledge the financial support received from the Deanship of Scientific Research, The University of Jordan. In addition, we would like to thank Miss. Zena Asfour and Mr. Mohammad Al Bashir for being research assistants throughout this empirical paper.

\section{References}

Almazari, A. (2011). Financial Performance Evaluation of Some Selected Jordanian Commercial Banks. International Research Journal of Finance and Economics, (68), 50-63.

Alzoubi, T. (2015). Profitability Comparison of Islamic and Conventional Banks. Proceedings of 4th European Business Research Conference, 9 - 10 April 2015, Imperial College, London, UK.

Bailey-Tapper S.A. (2010). Non-interest Income, Financial Performance \& the Macroeconomy: Evidence on Jamaican Panel Data. Financial Stability Department, Bank of Jamaica.

Bashir, A. (2003). Determinants of Profitability in Islamic Banks: Some Evidence from the Middle East. Islamic Economic Studies, 11(1), 31-57.

Bian, W., Wang, X., \& Sun, Q. (2015). Non-interest Income, Profit, and Risk Efficiencies: Evidence from Commercial Banks in China. Asia-Pacific Journal of Financial Studies, 44(5).

Damankah, B.S., Anku-Tsede, O., \& Amankwaa, A. (2014). Is Traditional Banking Declining? An Empirical Analysis of Banks in Ghana. International Journal of Academic Research in Accounting, Finance and Management Sciences, 5(1), 27-32.

DeYoung, R., \& Rice, T. (2003). Noninterest Income and Financial Performance at U.S. Commercial Banks. Policy Studies: Supervision and Regulation Department, Federal Reserve Bank of Chicago, Emerging Issues Series.

DeYoung, R., \& Roland, K. (2001). Product Mix and Earnings Volatility at Commercial Banks: Evidence from a Degree of Leverage Model. Journal of Financial Intermediation, 10(1), 54-84.

Edirisuriya, P., Gunasekarage, A., \& Dempsey, M. (2015). Australian Specific Bank Features and the Impact of Income Diversification on Bank Performance and Risk. Australian Economic Papers, 54(2).

Haron, S. (1996). Competition and Other External Determinants of the Profitability of Islamic Banks. Islamic Economic Studies, 4(1), 49-64.

Karakaya, A., \& Er, B. (2013). Noninterest (Nonprofit) Income and Financial Performance at Turkish Commercial and Participation Bnaks. International Business Research, 6(1), 106-117.

Rahman, et.al. (2015). A Comprehensive Review of Microfinance Impacts, Sustainability and Outreach. Asian Journal of Agricultural Extension, Economics \& Sociology, 6(2), 64-76.

Rogers, K., \& Sinkey, J.F., Jr. (1999). An analysis of nontraditional activities at U.S. commercial banks. Review of Financial Economics, 8, 25-39.

Rogers, K.E. (1998). Nontraditional activities and the efficiency of US commercial banks. Journal of Banking and Finance, 22, 467-482.

Stiroh, K. (2002). Diversification in Banking: Is Noninterest Income the Answer?. Staff Reports No. 154, Federal Research Bank of New York. 